\title{
The Effect of Financial Performance on the Profitability of Food and Beverage Companies in Indonesia
}

\author{
Herdiyana $^{1}$, Adi Sumarno ${ }^{2} \&$ Endri Endri ${ }^{2}$ \\ ${ }^{1}$ Universitas Pakuan, Bogor, Indonesia \\ ${ }^{2}$ Universitas Mercu Buana, Jakarta, Indonesia \\ Correspondence: Endri Endri, Lecturer, Universitas Mercu Buana, Jakarta, Indonesia.
}

Received: July 17, 2020

doi:10.5430/ijfr.v12n1p30
Accepted: September 1, 2020

Online Published: December 24, 2020

URL: https://doi.org/10.5430/ijfr.v12n1p30

\begin{abstract}
This study aims to determine the effect of the company's financial performance which is calculated from total assets, net capital and total asset turnover on the profitability of the food and beverage sub-sector companies listed on the Indonesian Eefek Exchange in the period 2015-2018. The method is done by collecting secondary data taken from the company's financial statements on the IDX. The research test tool used descriptive statistical analysis and the inference of the multiple linear regression method. The results showed that total assets, net working capital and total assets turnover independently had no significant and significant effect on profitability as well as join contribution also had no effect but could make a small contribution to the profitability of food and beverage sub-sector companies listed in IDX.
\end{abstract}

Keywords: financial performance, total assets, net working capital, total asset turnover and profitability

\section{Introduction}

Since the company was first formed, the goal is clear, to achieving maximum profit or in other words the company must carry out activities effectively and efficiently. Effectiveness is related to the goals to be achieved, while efficiency is related to the smallest possible cost to achieve goals (Martono \& Harjito, 2005). Profit is the difference between income that occurs or arises from transactions during one period and each expense from that income (Shahnia et al. 2020). In theory, profit is a relationship between the revenue earned by the company on the one hand with costs that are expenses or incurred on the other. If the income is obtained maximally with very minimal costs incurred, then the maximum profit will be realized (Rusdana \& Endri, 2020).

Profitability illustrates the ability of companies to earn profits, the greater the level of profits, indicating the better management of the company (Sari \& Endri, 2019). The concept of profitability is one of the strategic parameters to measure whether a company is run in a fairly efficient manner. The level of efficiency will be seen after comparing the profits obtained with active or capital that is able to produce these profits, so that profitability can be interpreted as the company's ability to earn profits related to sales, total assets, and long-term debt (Harahap et al. 2020). Profitability also reflects the benefits of financial investment (Harahap, 2019). Profitability Ratio is a ratio used to see the extent of the company's ability to manage finances in order to get profits in relation to sales, total assets and capital spent (Rinaldo \& Endri, 2020). For investors and shareholders, the profitability ratio is closely related to the stock price and dividends that will be obtained. The way to assess the profitability of a company can vary depending on the profit and capital used associated with the company's operations or net profit after tax.

In Indonesia, food and beverage companies are still marketable because they have a very important role in the development of the industrial sector, especially in its contribution to non-oil and gas GDP revenues (Endri et al. 2020). On the other hand, a very potential market share in Indonesia can drive growth of food and beverage sub-sector industry. Based on data from the Ministry of Industry, Indonesian food and beverage products were able to record the highest export value in the manufacturing group, with an achievement of USD27.28 billion during 2019. In addition, the food and beverage industry is also the largest depositor of the value of investment in the January-September 2019 period in numbers Rp.41.43 trillion. Furthermore, the food and beverage industry absorbs the most workers in the manufacturing sector with a total of 4.74 million people until August 2019. 
Although the Indonesian food and beverage industry market is still very promising and this industry provides the largest contribution after non-oil and gas, it can be seen from the growth of the food and beverage industry which tends to experience a decline in growth of $7.91 \%$ in 2018 compared to before two years amounted to $9.23 \%$ and in 2016 amounted to $8.33 \%$. The decline from the previous two years was caused by the condition of the national economy due to the decline in world palm oil prices, which also reflected the financial performance of the food and beverage sub-sector. Based on data processed from the food and beverage sub-sector financial reports, the average level of profitability of the food and beverage subsector shows fluctuating conditions and even tends to decline throughout the 2015-2018 period, this shows the company's financial performance in 2015, asset value management, total assets, accounts receivable turnover, inventory turnover, and total asset turnover which are still not effective or not well managed. With the condition of financial performance and profitability during 2015-2018, changes in unfavorable fluctuations for food and beverage sub-sector companies are the main motivation for research. The purpose of this study is to describe the effect of total assets, working capital, and total asset turnover on profitability, and whether it simultaneously affects profitability in food and beverage sub-sector companies listed on the Indonesia Stock Exchange during 2015-2018.

\section{Literature Review}

\subsection{Financial Performance}

Financial performance is a picture of the company's financial condition that is analyzed through a series of financial analysis tools, so it can know the position and level of soundness of the company's financial condition that can also reflect work performance in a certain period. The concept of financial performance according to Shahnia \& Endri (2020) is a set of financial activities over a certain period reported in the financial statements and income statement. Meanwhile, according to Doorasamy (2016) financial performance as an analysis conducted to determine the extent to which a company has carried out financial procedures and is good and right. According to Prabowo \& Korsakul (2019) convinced that the true parameters of financial performance are the income statement, and net income and expenses. The benefits of this performance appraisal include; measure the achievements of the company in a certain period, see the company's overall performance, as a basis for determining future corporate strategy, provide direction in decision making, as well as as basis for determining investment policies for investors.

\subsection{Total Assets (TA)}

The company can be measured by the amount of assets owned. The size of the company is very influential on the capital used, moreover closely related to the company's ability to obtain additional capital from the investor when the cost of expenditure cannot be supported from existing funds (Firdaus \& Endri, 2020). To see the size of the company can also refer to the number of employees, total assets owned, the number of sales and market capitalization. Based on this reference, company size can be divided into large, medium and small companies (Nicolescu, 2001). In principle there are two views regarding the relationship between company size and profit. First view reveals that company size has a positive correlation with earnings. The size of the company, which is greater, the benefits to be obtained will increase (Daeli \& Endri, 2018). The second view that reveals that company size does not have a correlation with earnings management means that small companies are not closed to the possibility of requiring large capital to drive the company's operational wheels. This can happen because small companies tend to want to show the condition of companies that always perform well to attract investors (Jao \& Pagulung, 2011).

\subsection{Net Working Capital (NWC)}

In essence, every company needs working capital used to support its operational needs, such as salaries, raw materials for production, electricity, and advertising financing. Working capital is the amount of current assets that is part of an investment that rotates from one form to another in business (Gitman, 2001). This investment can be in the form of short-term assets or in current assets which can be categorized into two, namely gross working capital and net working capital. Working capital management manages current assets and current debt so that current assets are always greater than current debt. Working capital management is also a company's investment in the short term in the form of cash, securities, receivables and inventories (Deloof, 2003). Working capital can be financed from own capital, both from short-term and long-term debt. Expenditure mechanism to be taken must be based on consideration of profits and risks that arise therefore it should be financed with as little capital as possible. The principle that can be taken in financing can be, working capital obtained as a short-term loan is only used to finance operational, whereas if as a long-term loan, it can be used for investment (Raheman \& Nasr, 2007). With sufficient working capital, the company can operate economically and efficiently and avoid liquidity risk. To determine the amount of working capital, usually used several methods such as the attachment of funds and working capital turnover (Ricci \& Vito 2000). Control of the 
appropriate amount of working capital will guarantee operational sustainability. If the working capital is too large then the embedded funds will exceed the needs so that it can result in idle funds.

\subsection{Total Assets Turnover (TATO)}

Activity ratio is the ratio used to assess the effectiveness of a company in using its assets / assets. This ratio is also used to compare sales results with assets owned by the company (Shahnia \& Endri, 2020). Components as financial backers must be managed well so that they can be utilized optimally. The more effective in managing funds means the faster the asset turnover. One way to measure activity ratios is through total asset turnover, which is the ratio between sales and total assets (Doorasamy, 2016). The greater this ratio indicates the company is able to manage its assets effectively (Harahap, 2018).

\subsection{Return on Assets (ROA)}

ROA is one of the components used to measure the company's ability to obtain overall profits. This component can also be an illustration of company performance efficiently. The higher ROA the greater the level of profit achieved, and the better the company in managing assets. ROA also provides an overview of companies in managing existing assets to get income (Endri, 2012). According to Prabowo \& Korsakul (2019). Brigham \& Houston (2010) returns on ROA are calculated by comparing the net income available to shareholders with total assets, the greater the ROA the higher the rate of return for investment. The advantage of ROA as a parameter in the level of profitability is the ease in its calculation and easy to understand, it becomes a measurement tool for management's persuasion in managing assets, almost all management focuses on maximum profitability, and as a tool for evaluating management policies. But on the other hand ROA also has shortcomings, among others, less encouraging additional assets when the ROA target is too high, management tends to focus on short-term targets rather than long, so that the policies made sometimes ignore the impact on ROA

\section{Research Methods}

This research is a descriptive study with a quantitative approach. The data used in this study are secondary data based on the company's financial statements which are also published on the Indonesia Stock Exchange.The population in this study consisted of 5 food and beverage companies listed on the Indonesia Stock Exchange for the period 2015-2018. As for consideration, companies that issue complete and consistent financial statements and are able to generate profits. Whereas the independent variables in this research are working capital (networking capital), total assets, as well as the ratio of activities to parameters in the form of total assets turnover (TATO), and the dependent variable is profitability. Data processing is done by SPSS and testing is done by using multiple regression tests with the following models:

$$
\mathrm{ROA}_{\mathrm{ti}}=\beta_{0}+\beta_{1} \mathrm{TA}_{\mathrm{ti}}+\beta_{2} \mathrm{NWC}_{\mathrm{ti}}+\beta_{2} \mathrm{TATO}_{\mathrm{ti}}+\mathrm{e}_{\mathrm{ti}}
$$

Remarks:

$\begin{array}{ll}\text { ROA } & =\text { Return on Asset } \\ \text { TA } & =\text { Total Asset } \\ \text { NWC } & =\text { Net working Capital } \\ \text { TATO } & =\text { Total Asset Turnover } \\ \mathrm{B}_{2}, \beta_{2}, \beta_{3} & =\text { Partial regression coefficient } \\ \mathrm{E} & =\text { Error term }\end{array}$

\section{Result and Discussion}

\subsection{Research Result}

\section{Descriptive Statistical Analysis}

Based on the results of descriptive statistical tests it can be seen that the highest value of the independent variable, namely from TA is $965.74 \%$ and the lowest value is $3.77 \%$ with an average value of $215.78 \%$. While the highest value for NWC was $177.09 \%$ and the lowest value was $0.31 \%$ with an average value of $341.62 \%$. Then for the highest value of TATO of $1.43 \%$ and the lowest value of $0.51 \%$ with an average value of $0.88 \%$. While for the dependent variable namely profitability calculated from ROA obtained the highest value of $0.18 \%$, the lowest value of $0.06 \%$ and an average value of $0.10 \%$. 
Table 1. Descriptive statistics

\begin{tabular}{|c|c|c|c|c|c|}
\hline & $\mathrm{N}$ & Minimum & Maximum & Mean & Std. Deviation \\
\hline TA & 20 & 377 & 96574 & 21578.05 & 35444.551 \\
\hline NWC & 20 & 31 & 17709 & 3416.25 & 4881.680 \\
\hline TATO & 20 & 51 & 143 & 88.50 & 24.414 \\
\hline ROA & 20 & 6 & 18 & 10.95 & 3.441 \\
\hline
\end{tabular}

\section{Residual Normality Analysis}

Normality test in the regression model is used to test whether the residual value is normally distributed or not. A good regression model is one that has a normally distributed residual value. Residual is the difference between the ROA variable and the predicted ROA variable. The way to detect it is to look at the spread of data at the diagonal source on the standardized P-P Normal Plot of regression standardized chart as a basis for decision making. If it spreads around a line and follows a diagonal line, the regression model is normal and feasible to predict independent variables and as well as the reverse. The normality test results can be seen in the Regression output in the Chart Normal P-P plot image. It can be seen that the points spread around the line and follow the diagonal line, the regression model is normal. Another way to test normality is the Kolmogorov Smirnov Z One Sample test method. The testing criteria are as follows (Priyatno, 2013):

- If the Significance value (Asym Sig 2 tailed) $>0.05$, then the data is normally distributed.

- If the Significance value (Asym Sig 2 tailed) $\leq 0.05$, then the data is not normally distributed.

Table 2. Kolmogorov-Smirnov Test

\begin{tabular}{lll}
\hline & & $\begin{array}{l}\text { Unstandardized } \\
\text { Residual }\end{array}$ \\
\hline $\mathrm{N}$ & & 20 \\
Normal Parameters $^{\mathrm{a}}$ & Mean & .0000000 \\
& Std. Deviation & 2.86306862 \\
Most Extreme Differences & Absolute & .149 \\
& Positive & .149 \\
& Negative & -.109 \\
Kolmogorov-Smirnov Z & & .668 \\
Asymp. Sig. (2-tailed) & & .763 \\
\hline
\end{tabular}

\section{a. Test distribution is Normal.}

From the above output it can be seen that the significance value (Asym.sig 2 tailed) is $0.763>0.05$, so the residuals are normally distributed.

\section{Multicollinearity Test Results}

Is a state where there is a perfect or near perfect linear relationship between independent variables in the regression model. A regression model is said to experience multicollinearity if there is a perfect linear function on some or all of the independent variables in a linear function, and the results are difficult to find the effect between the independent and dependent variables.

The way to find out whether or not there is a multicollinearity problem is by looking at the value of Variance Inflation Factor (VIF) and Tolerance, if the VIF value is less than 10 and Tolerance is more than 0.100 , then multicollinearity is declared. 
Table 3. Multicollinearity Analysis Test

\section{Coefficients $^{\mathrm{a}}$}

\begin{tabular}{|c|c|c|c|c|c|c|c|}
\hline \multirow[b]{2}{*}{ Model } & \multicolumn{3}{|c|}{ Unstandardized Coefficients Standardized Coefficients } & \multirow[b]{2}{*}{$\mathrm{t}$} & \multirow[b]{2}{*}{ Sig. } & \multicolumn{2}{|c|}{ Collinearity Statistics } \\
\hline & B & Std. Error & Beta & & & Tolerance & VIF \\
\hline 1 (Constant) & 13.384 & 5.136 & & 2.606 & .019 & & \\
\hline TA & $-3.448 \mathrm{E}-5$ & .000 & -.355 & -.633 & .536 & .164 & 6.088 \\
\hline NWC & .000 & .000 & .557 & 1.580 & .134 & .417 & 2.401 \\
\hline TATO & -.034 & .067 & -.243 & -.515 & 614 & .232 & 4.308 \\
\hline
\end{tabular}

a. Dependent Variable: ROA

It can be seen that there is no multicollinearity problem, this can be seen from the VIF value for the three independent variables less than 10, and the tolerance value is more than 0.100 .

\section{Heteroscedasticity Test Results}

Heteroscedasticity is a condition where there is a variance in residual variance for all observations in the regression model. Heteroscedasticity can be detected by looking at the dotted pattern in the scatter plot regression. If the points spread with unclear patterns above and below the number 0 on the Y-Axis then there is no heteroscedasticity problem. Heteroscedasticity test results can be seen in the output Regression on the Scatterplot image, it can be seen that the points spread with unclear patterns above and below the number 0 on the $\mathrm{Y}$ axis, so it can be concluded that there is no heterocedasticity problem in the regression model. Note: The heteroscedasticity test of the graphical method can make decisions that vary between hetero or not, because it is only based on looking at chart patterns, therefore it is necessary to perform statistical tests such as the Glejser Test for more valid test results. Another way to test heteroscedasticity is the Glejser Test. The Glejser test is performed by estimating the independent variables at their absolute residual values. The residual is the difference between the value of the variable $\mathrm{Y}$ and the predicted value of the variable Y (all values are positive). If the significance value between the independent variables and absolute residuals is more than 0.05 , then there is no heteroscedasticity problem.

Table 4. Glejser Analysis Test

\section{Coefficients $^{\mathrm{a}}$}

\begin{tabular}{|c|c|c|c|c|c|c|}
\hline & \multirow[b]{2}{*}{ Model } & \multicolumn{2}{|c|}{ Unstandardized Coefficients } & $\begin{array}{l}\text { Standardized } \\
\text { Coefficients }\end{array}$ & \multirow[b]{2}{*}{$\mathrm{t}$} & \multirow[b]{2}{*}{ Sig. } \\
\hline & & $\mathrm{B}$ & Std. Error & Beta & & \\
\hline \multirow[t]{4}{*}{1} & (Constant) & 5.978 & 1.824 & & 3.278 & .005 \\
\hline & TA & $2.877 \mathrm{E}-5$ & .000 & .813 & 1.487 & .156 \\
\hline & NWC & $-7.871 \mathrm{E}-5$ & .000 & -.306 & -.893 & .385 \\
\hline & TATO & -.043 & .024 & -.841 & -1.828 & .086 \\
\hline
\end{tabular}

a. Dependent Variable: ABS_RES

Heteroscedasticity test results can be seen that the three independent variables have a significance value of more than 0.05 , so it can be concluded that there is no heteroscedasticity problem in the regression model.

Autocorrelation Test Results

Autocorrelation is a condition where in the regression model there is a correlation between residuals in period $t$ with residuals in the previous period ( $\mathrm{t}-1)$. A good regression model is one in which there is no autocorrelation problem. Decision making in the autocorrelation test as follows:

Autocorrelation test can be done by testing Durbin Watson (DW), the following decision-making criteria: 
- $\quad 1,65<\mathrm{DW}<2,35$, that means there is no autocorrelation

- $1,21<\mathrm{DW}<1,65$ atau 2,35 $<\mathrm{DW}<2,79$ the meaning cannot be concluded

- $\mathrm{DW}<1,21$ atau $\mathrm{DW}>2,79$ means autocorrelation

Table 5. Autocorrelation Analysis Test

\begin{tabular}{rrrrrr}
\multicolumn{6}{c}{ Model Summary $^{\mathbf{b}}$} \\
\hline Model & R & R Square & Adjusted R Square & $\begin{array}{c}\text { Std. Error of the } \\
\text { Estimate }\end{array}$ & Durbin-Watson \\
\hline 1 & $.415^{\text {a }}$ & .173 & .017 & 3.411 & .562 \\
\hline
\end{tabular}

a. Predictors: (Constant), TA, NWC, TATO

b. Dependent Variable: ROA

From the above output it can be seen that there is an autocorrelation problem, this is because the Durbin Watson (DW) value of 0.562 is less than 1.21 which indicates autocorrelation. Note: The autokoleration test is intended to see whether observations in year $t$ are influenced by the previous year $(\mathrm{t}-1)$, which means that the autokoleration test is performed for time series data. Panel data does not require autokoleration test because company year $\mathrm{X}$ data will not affect the $\mathrm{Y}$ year company data of the previous year so the panel data regression model does not require an autocorrelation free equation. With this, based on the theory, in this study even though autocorrelation occurred but the regression results remain valid.

\section{Results of Multiple Linear Regression Analysis}

Multiple linear regression analysis is used to determine the effect of the independent variables on the dependent variable either partially ( $\mathrm{t}$ test) or together ( $\mathrm{F}$ test). The multiple linear regression equation is used to formulate the regression equation and to find out the value of the increase or decrease in variable ROA for changes in independend variable. The results obtained after the data are processed with the help of the SPSS program are presented in the following table:

Table 6. Multiple Linear Regression Result

Coefficients $^{\mathrm{a}}$

\begin{tabular}{|c|c|c|c|c|c|c|c|c|}
\hline \multirow[b]{2}{*}{ Model } & \multicolumn{4}{|c|}{ Unstandardized Coefficients Standardized Coefficients } & \multirow[b]{2}{*}{$\mathrm{t}$} & \multicolumn{3}{|c|}{ Collinearity Statistics } \\
\hline & B & Std. Error & Beta & & & Sig. & Tolerance & VIF \\
\hline 1 (Constant) & 13.384 & 5.136 & & & 2.606 & .019 & & \\
\hline TA & $-3.448 \mathrm{E}-5$ & .000 & & -.355 & -.633 & .536 & .164 & 6.088 \\
\hline NWC & .000 & .000 & & .557 & 1.580 & .134 & .417 & 2.401 \\
\hline TATO & -.034 & .067 & & -.243 & -.515 & 614 & .232 & 4.308 \\
\hline
\end{tabular}

a. Dependent Variable: ROA

The regression equation is as follows:

$\mathrm{ROA}_{\mathrm{it}}=13,384-3,448 \mathrm{E}-5 \mathrm{TA}_{\mathrm{it}}+0,000 \mathrm{NWC}_{\mathrm{it}}-0,034 \mathrm{TATO}$ it 
Table 7. F Test Result

ANOVA $^{b}$

\begin{tabular}{rrrrrrr}
\hline & Model & Sum of Squares & df & Mean Square & F & \multicolumn{1}{c}{ Sig. } \\
\hline 1 & Regression & 38.812 & 3 & 12.937 & 1.112 & $.373^{\mathrm{a}}$ \\
& Residual & 186.138 & 16 & 11.634 & & \\
& Total & 224.950 & 19 & & & \\
\hline
\end{tabular}

a. Predictors: (Constant), TATO, NWC, TA

b. Dependent Variable: ROA

Table 8. Determination Analysis Test

\begin{tabular}{rrrrrr}
\multicolumn{6}{c}{ Model Summary $^{\mathbf{b}}$} \\
\hline Model & R & R Square & Adjusted R Square & Std. Error of the \\
Estimate & Durbin-Watson \\
\hline 1 & $.415^{\text {a }}$ & .173 & .017 & 3.411 & .562 \\
\hline
\end{tabular}

a. Predictors: (Constant), TA, NWC, TATO

b. Dependent Variable: ROA

\subsection{Discussion}

\section{The Effect of Total Assets on Profitability}

Based on the results of the coefficient test from multiple linear regression analysis, it illustrates that the total assets partially do not affect the level of profitability in this case represented by ROA. This can be seen from the significance value of the variable total assets (TA) of 0.633 greater than -2.120 or 0.536 greater than 0.05 . This means that the greater the assets owned have no effect and are not able to move and have an impact on the level of profitability, and vice versa. The results of this study are consistent with research conducted by Talebnia et al. (2010) Fachrudin \& Amalia (2011) and Putra \& Badjra (2015) which explains that total assets are not a major factor that can affect profitability. This result can also be understood that if assets increase, profitability will actually move down and as well as the reverse one. According to Fahrudin (2011) the number of assets is not a guarantee that the company has the ability to generate large profits. The absence of this influence can also be understood that the greater the assets of the company also indicates the more cost of activities to be able to support operations both labor, maintenance and repair assets, as well as administrative costs and energy costs, so as to reduce the level of profitability. The results of other studies indicated by Ambarwati et al. (2015) that total assets significantly influence the level of profitability. This indicates that the more the maximum asset management, the more profit will be obtained, because the assets are actually used operationally to support sales. In other words, assets can degenerate well to generate profits. This is in line with the opinion of Nuriyah et al. (2018) which says that companies with large assets describe the reliability of the establishment and the ability of the company.

\section{The Effect of Net Working Capital on Profitability}

Based on the results of multiple linear regression statistical tests on the variable net working caital it is found that the coefficient of net working capital of 1.580 is smaller than 2.120 or 0.134 is greater than 0.05 . This shows that net working capital has no significant effect on profitability, which in this case is represented by ROA. This also indicates that the amount of capital does not have an impact on increasing profitability, and vice versa, the small capital does not mean unable to encourage profitability. This means that capital is not the main factor in determining the occurrence of profits in the food and beverage sub-sector companies during 2015-2018. This is in line with the results of Deloof (2003), which explains that the working capital component in the form of cash flow turnover partially has no effect on profitability on the financial performance of the 2008-food and beverage sub-sector companies. 2010. This is due to pressure on the level of accounts receivable, inventory and investment strategies so that it can disrupt the availability of cash reserves to support the company's operational activities. The same result was also conveyed by Nawalani \& Lestari (2014) that the working capital component in the form of cash flow has no effect on profitability, which means the shorter time period in selling credit makes the cash turnover faster and makes the company unable to increase sales significantly so profitability dropped. This is not in accordance with the theory that cash turnover has a 
positive effect on profitability. Other results on working capital are shown by Virgadinda \& Elmanizar (2019) that working capital has a significant effect on profitability. The higher the working capital, the higher the profit level will be. This is in line with the theory of Sivilianto \& Endri (2019) which explains that the working capital turnover rate shows the effective use of working capital, or in other words the faster the working capital rotates the greater the benefits to be gained.

\section{The Effect of Total Asset Turnover on Profitability}

The ratio of total assets turnover becomes a measurement tool for optimizing the total assets available to produce sales volume in a certain period. The results of the statistical test of TATO variable on profitability (ROA) through multiple linear regression showed that the TATO coefficient of 0.515 was greater than -2.120 or a significance value of 0.614 was greater than 0.05 . These results illustrate that TATO has no effect and is significant on the level of profitability (ROA). In other words, however optimal the asset management is, it does not have an impact or is still low on sales volume, or the faster the rotation of assets owned does not affect the profit. The above results are in line with the results of research from Endri (2018) which explains that the total asset turnover ratio (TATO) has no significant effect on profitability (ROA). This illustrates that the higher total asset turnover ratio does not necessarily cause a high level of company profitability. If the total asset turnover ratio continues to be increased by streamlining and streamlining the source of funds owned, the profitability trend will also increase. A high total asset turnover ratio actually describes the efficiency of using assets held to encourage sales at a certain volume. It can also be interpreted that the asset turnover ratio still has a low impact on profits in the food and beverage sub-sector companies. The results of other studies were obtained from Gunawan (2019); Endri et al. (2019) who revealed that TATO partially influences profitability. It also explains that the higher the level of activity and asset turnover, the better it will generate profits. This is also supported by the theory put forward by Rusdana \& Endri (2020) where the activity ratio is the ratio to assess the company's ability in sales and the company's ability in day-to-day management.

\section{The Effect of Total Assets, Net Working Capital and Total Turnover Assets Simultaneously on Profitability}

The $\mathrm{F}$ test is used to determine the effect of the independent variables on the dependent variable simultaneously. Based on the statistical test results the calculated $F$ value of 1.112 is smaller than the $F$ table of 3.239 with a significance value of 0.373 , greater than 0.05 . This indicates that the variable total assets, net working capital and total asset turnover together have no effect and have a low significance of profitability (ROA). This means that the merging of total assets, capital management, and effective working capital turnover has not been able to influence and impact on profit growth. However, if managed properly and carried out in an integrated and effective manner, also by prioritizing various budget posts, it will have an impact on increasing profits.

\section{Conclusion}

Based on the results of the above research it can be concluded that total assets has no effect and is not significant to profitability in the food and beverage sub-sector companies listed on the IDX. This shows that if the size of the company increases, the profitability of the company will decrease and this can also mean that the size of the company is not a major factor that can affect profitability. Because the larger the size of the company, of course, will increasingly require a large cost to be able to support the company's operational activities, so that it will reduce profits.

In terms of working capital (net working capital) also has no effect and is not significant to profitability (ROA). This is due to the addition of cash and cash equivalents due to the suppression of inventory levels, trade receivables in line with sales increases and purchases of investment assets. This can also be interpreted if it turns out that working capital is not the main factor that can affect profitability if the management is not right and will be more absorbed in posts outside of the company's operations that support sales.

While the aspect ratio of activity represented by the total asset turnover parameter also has no effect and is not significant to profitability (ROA) in the food and beverage sub-sector companies listed on the IDX. This illustrates that the higher total asset turnover ratio does not necessarily cause a high level of company profitability. If the total asset turnover ratio continues to be increased by streamlining and streamlining the source of funds owned, the profitability trend will also increase. A high total asset turnover ratio indicates the more efficient use of assets owned to boost sales levels at a certain volume. It can also be interpreted that the asset turnover ratio still has a low impact on profits in the food and beverage sub-sector companies. Simultaneously that total assets, working capital and activities also have no effect on profits but can provide sufficient influence on increasing profits. This means that if it is managed properly and carried out in an integrated and effective manner as well as prioritizing various budget posts, it will have an impact on increasing profits. So that total assets, working capital and activities have a significant and 
positive impact on profitability, it is important to note, among others, the company is more focused on effective capital management that can support the company's operations and can directly impact on profits, more restraint and manage receivables properly, withholding asset purchases and reducing the supply of materials that are too high. Management of the company's operations more effectively and efficiently by reducing things that do not provide added value and focusing activities that are more profitable. Increase the total asset turnover ratio through managing assets properly to meet the company's operational activities as well as accelerating refunds and increasing profitability.

\section{References}

Ambarwati, N. S., Yuniarta, G. A., \& Sinarwati, Y. N. (2015). Pengaruh Modal Kerja, Likuiditas, Aktivitas, dan Ukuran Perusahaan Terhadap Profitabilitas Pada Perusahaan Manufaktur Yang Terdaftar di Bursa Efek Indonesia. E-Jurnal S1 Ak Universitas Pendidikan Ganesha, 3(1), 1-11.

Daeli, C., \& Endri. (2018). Determinants of Firm Value: A Case Study of Cigarette Companies Listed on the Indonesia Stock Exchange .International Journal of Managerial Studies and Research (IJMSR), 6(8), 51-59.https://doi.org/10.20431/2349-0349.0608006

Deloof, M. (2003). Does Working Capital Management Affects Profitability of Belgian Firms?. Journal of Business Finance \& Accounting, 30(3\&4), $573-587$.

Doorasamy, M. (2016). Using DuPont analysis to assess the financial performance of the top 3 JSE listed companies in the food industry. Investment Management and Financial Innovations, 13(2), 29-44.

Endri (2012). Pengaruh Mekanisme Corporate Governance Terhadap Kinerja Profitabilitas Perbankan Syariah di Indonesia. Jurnal Keuangan dan Perbankan, 16(2), 264-274.

Endri, E., Dermawan. D., Abidin. Z., \& Riyanto. S. (2019). Effect of Financial Performance on Stock Return: Evidence from the Food and Beverages Sector. International Journal of Innovation, Creativity and Change, 9(10), 335-350.

Endri, E., Sumarno, A., \& Saragi, H. (2020). Analysis of Financial Performance: Evidence from Food and Beverage Companies in Indonesia. International Journal of Advanced Science and Technology, 29(5), 4199-4208.

Endri. (2018). Impact of Intellectual Capital and Efficiency to the Profitability of Islamic Banking. International Journal of Science and Research (IJSR), 7(7), 230-237

Fachrudin., \& Amalia, K. (2011). Analisis Pengaruh Struktur Modal, Ukuran Perusahaan, dan Agency Cost Terhadap Kinerja Perusahaan. Jurnal Akuntansi Keuangan, 13(1), 37-46

Firdaus, F., \& Endri, E. (2020). Financial Statement Analysis: Evidence from Indonesian Bank BUKU IV. International Journal of Innovative Science and Research Technology, 5(4), 455-461.

Gitman, L. J. (2001). Principle of Managerial Finance. Harper International Edition. Harper \& Row Publisher, New York, Hagerstown, San Francisco.

Gunawan, H. (2019). Pengaruh Aktivitas, Solvabilitas, dan Ukuran Perusahaan Terhadap Profitabilitas Perusahaan Manufaktur Sub-Sektor Makanan dan Minuman Di Bursa Efek Indonesia. Jurnal Manajemen Bisnis dan Kewirausahaan,4(2), 81-86.

Harahap, I. M. (2018). Impact of Bank Performance on Profitability. Scholars Journal of Economics, Business and Management, 5(8), 727-733.

Harahap, I. M., Septiania, I., \& Endri, E. (2020). Effect of financial performance on firms' value of cable companies in Indonesia. Accounting, 6(6), 1103-1110. https://doi.org/10.5267/j.ac.2020.7.008

Jao, R., \& Pagulung, G. (2011). Corporate Governance, Ukuran Perusahaan, dan Leverage Terhadap Manajemen Laba Perusahaan Manufaktur Indonesia. Jurnal Akuntansi \& Auditing, 8(1), 1-94.

Martono, \& Harjito, D. A. (2005). Financial management. First edition of the fifth printing. Yogyakarta. Ekonisia Publisher.

Nawalani, A. P., \& Lestari, W. (2015). Pengaruh Modal Kerja Terhadap Profitabilitas Pada Perusahaan Food and Beverages di Bursa Efek Indonesia. Journal of Business and Banking, 5(1), 51-64. https://doi.org/10.14414/jbb.v5i1.379

Nicolescu, O. (2001). Small and medium-sized enterprises management. Economic Publishing House, Bucharest. 
Nuriyah, A., Endri. E., \& Yasid, M. (2018). Micro, Small-Financial Financing and its Implications on the Profitability of Sharia Banks. DeReMa Jurnal Manajemen, 13(2), 175-197.

Prabowo, S. C. B., \& Korsakul, N. (2019). Analysis of Financial Performance of Mining Companies Listed in Indonesia Stock Exchange. Journal of Applied Management (JAM), 18(1), 28-45.

Raheman, A., \& Nasr, M. (2007). Working Capital Management And Profitability - Case Of Pakistani Firms. International Review of Business Research Papers, 3(1), 279-300

Ricci, C., \& Vito, N. D. (2000). International Working Capital Practices in the UK. European Financial Management, 6(1), 69-84.

Rinaldo, N. E., \& Endri, E. (2020). Analysis of Financial Performance of Plantation SubSector Companies Listed on the Indonesia Stock Exchange for the 2014-2019 Period. International Journal of Innovative Science and Research Technology, 5(4), 530-537.

Rusdana, F., \& Endri, E (2020). Analysis of Financial Performance Tobacco Listed in Indonesia Stock Exchange. JKBM (Jurnal Konsep Bisnis dan Manajemen), 6(2), 179-187.

Sari, F. N., \& Endri, E. (2019). Determinants of Return on Assets (ROA) On Conventional Banks Listed On Indonesian Stock Exchange (IDX) Period 2013 - 2017. IOSR Journal of Business and Management (IOSR-JBM), 21(4. Ser.II), 52-62. https://doi.org/10.9790/487X-2104025262

Shahnia, C., \& Endri, E. (2020). Dupont Analysis for the Financial Performance of Trading, Service \& Investment Companies in Indonesia. International Journal of Innovative Science and Research Technology, 5(4), 193-211.

Shahnia, C., Purnamasari, E. D., Hakim, L., \& Endri, E. (2020). Determinant of profitability: Evidence from trading, service and investment companies in Indonesia. Accounting, 6(5), 787-794. https://doi.org/10.5267/j.ac.2020.6.004

Sivilianto, H., \& Endri, E. (2019). Determinants of External and Internal Stock Price of Coal Mining Subsector Companies Period 2005-2017. Scholars Bulletin, 5(4), 162-168. https://doi.org/10.21276/sb.2019.5.4.5.

Talebnia, G., Saleho, M., Hashem, V., \& Shafiee, S. (2010). Empirical Study of the Relationship Between Ownership Structure and Firm Performance: Some Evidence of Listed Companies in Tehran Stock Exchange. Journal of Sustainability Development, 3(2), 264-270.

Virgadinda, A., \& Elmanizar. (2019). Pengaruh Perputaran Modal Kerja, Likuiditas, dan Pertumbuhan Penjualan Terhadap Profitabilitas. Majalah Sainstekes, 6(2), 54-64.

\section{Copyrights}

Copyright for this article is retained by the author(s), with first publication rights granted to the journal.

This is an open-access article distributed under the terms and conditions of the Creative Commons Attribution license (http://creativecommons.org/licenses/by/4.0/). 